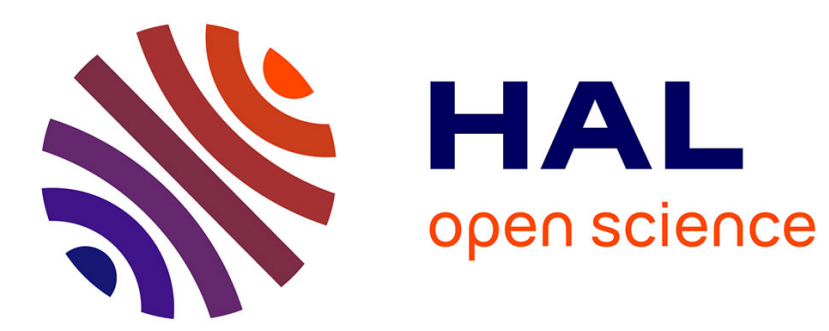

\title{
Public Safe Assets Determination
}

Ly Dai Hung

\section{- To cite this version:}

Ly Dai Hung. Public Safe Assets Determination. 2018. hal-01935126

\section{HAL Id: hal-01935126 \\ https://hal.science/hal-01935126}

Preprint submitted on 26 Nov 2018

HAL is a multi-disciplinary open access archive for the deposit and dissemination of scientific research documents, whether they are published or not. The documents may come from teaching and research institutions in France or abroad, or from public or private research centers.
L'archive ouverte pluridisciplinaire HAL, est destinée au dépôt et à la diffusion de documents scientifiques de niveau recherche, publiés ou non, émanant des établissements d'enseignement et de recherche français ou étrangers, des laboratoires publics ou privés. 


\title{
Public Safe Assets Determination
}

\author{
Hung Ly-Dai *
}

Octorber 2018

\begin{abstract}
We characterize the safety of public debt by one cross-section sample of 160 economies. For demand analysis, the public debt is safer for larger financial market size, higher financial development level, lower inflation rate and greater political stability. For supply analysis, by a huger debt stock, the safety improves in economies with high income per capita but deteriorates in economies with low income per capita. The results are robust for Instrument-Variable regressions.
\end{abstract}

Keywords: Safe Assets, Credit Ratings, Financial Development.

JEL classification: F21, F31, F41.

*Email: hunglydai@gmail.com. Faculty of International Business and Economics, VNU University of Economics and Business. Address: office 406, E4 building, 144 Xuan Thuy street, Cau Giay district, Ha Noi city, Viet Nam. The author thanks the helpful comments by Cuong Le-Van, Vo Tri Thanh, Vu Quoc Huy and participants on Economics Workshop at UEB-FIBE Department of World Economy and International Economic Relations, DEPOCEN Development and Policies Research Center, APIM Asia-Pacific Institute for Management. 


\section{Introduction}

The world economy, as shown by Caballero, Farhi and Gourinchas (2016), suffers from the scarcity of safe assets, which can in turn affect the current international monetary system. Bernanke (2010) argues that the huge demand for safe assets as store of wealth, backed by excess savings by developing economies, underlies the 2008 global financial crisis. Moreover, on Caballero, Farhi and Gourinchas (2017), the scare supply of safe assets can push the world main supplier of safe assets into the secular stagnation since it prevents the economy to stimulate the domestic aggregate demand by surplus trade balance. Therefore, the world economy can fall into the secular stagnation. In brief, the recent phenomena motivates a newly dynamic literature on safe assets.

There exists the research gap on the literature on determinants of safe assets. By definition, the safe assets can be information-insensitive assets with no moral hazards and adverse selection as on Dang, Gorton, Holmstrm and Ordonez (2017) or uncertainty-insensitive assets with constant rate of return in all realized states of world as on Caballero, Farhi and Gourinchas (2016). For the second concept, there are two main lines of research. On demand side, He, Krishnamurthy and Milbradt (2016) show that the safety of assets depends on the investor belief in the sense that if they believe an asset to be safe, theirs actions can make that asset safe. On supply side, Farhi and Maggiori (2017) argue that the debt safety depends on its supply. A too much debt issuance can turn the safe assets to be risky. However, the current literature focuses on the characteristics for one asset to be safe or not, giving away the safety level. Therefore, there is still mysterious question on the determinants of safe assets, and on their roles on affecting the safety.

Our paper aims to characterize the determinants of public safe assets. In details, we investigate both the factors from demand and supply side of public debts on one cross-section sample of about 160 economies. The demand analysis investigates the role of financial market size on ensuring the debt safety. And the supply analysis considers the impact of public debt stock on affecting the safe assets. Moreover, these analyses account for fundamentals of assets such as inflation rate, income per capita and for institutional quality such as financial development and political stability. In brief, the combination of demand and supply analysis lays the ground for public debt safety determination.

The paper is closely related to the theoretical literature on the safety of public debts, with one recent survey on Gorton (2017). He, Krishnamurthy and Milbradt (2017) show that the safety of sovereign debt depends on two characteristics. The debt is more likely to be safe if its fundamentals are strong relative to other assets and, with high demand for debt, its floating capacity is large. The fundamentals also contribute on the safety of 
debt on the framework by Farhi and Maggiori (2017). Indeed, when the issuer of debt, served as reserves assets, holds the monopoly power on supplying debt, its choice of optimal debt stock would take into account the expectation on the debt safety by foreign investors. When the debt stock is too high, i.e, passing one threshold grounded by fundamentals, the issuer has incentive to depreciate its currency to devalue the debt burden. The depreciation, in turn, makes the debt to be risky. However, these papers do not take into account the relative role of safe assets determinants since their focal point is on whether the debt is safe or not.

Our empirical evidences complement to the results on the aforementioned papers. We establish that a higher financial market size raises the debt safety but a huger debt stock can improve its safety only on the economies with high enough income per capita. Therefore, the income per capita plays one crucial role on shaping the impact of debt supply on its safety level. The result holds on controlling for other factors which captures the fundamentals of economy such as inflation rate, trade balance and the institution quality such as financial development and political stability. For example, if the stock market size of Mexico goes up from $6.17 \%$ to $40.96 \%$, as the level of Canada, its public debt safety could improve by one magnitude of 7.39 , from 12 to 19.39 within the index range from 1 to 21 for sovereign debt ratings. In short, accounting for relative role of public debt safety determinants is our contribution to the literature on safe assets.

The paper also belongs to the literature on sovereign credit ratings. Cantor and Packer (1996) employ the cross-section analysis to quantify the relative significant of determinants of sovereign ratings over 1991-1994. Their findings show that a higher income per capita and lower inflation rate appears to be closely related to high ratings. However, they do not control for debt supply as the key determinant of credit ratings. For one panel sample of about 60 economies over 1995-2005, Afonso, Gomes and Rother (2011) account for several macroeconomic and fiscal variables on determining the sovereign debt ratings. They show that income per capita and debt supply are short-run determinants while external debt and foreign reserves are long-run determinants. However, the authors neglect the role of financial market size which illustrates the effect of investor's demand on debt ratings.

Compared to these two papers, ours differs by two key features. Firstly, we take into account both demand side by the financial market size and supply side by the public debt stock on the determination of public debt ratings. Secondly, our evidences stress the role of income per capita to shaping the dependence pattern of public debt safety on its supply.

The paper processes as follows. Section (2) lays framework for estimation of public debt safety determination. Next, section (3) presents the empirical evidences for both demand and supply analysis. Finally, section (5) concludes and is followed by Appendix. 


\section{Estimation}

\subsection{Theoretical Motivation}

The determinants of public debt safety can be classified by demand and supply aspect. Indeed, the safety can depend on the assessment of investors who purchase debts as store of wealth or on the reputation of suppliers who issue debts as financing source for public expenditure.

For demand analysis, He, Krishnamurthy and Milbradt (2016) shows that the absolute debt capacity of one country can make its debt to be safe. Indeed, when the investors believe one asset to be safe, their action could make that asset safe. And the high debt capacity of the issuer could be potential to satisfy the demand by investor and ensure their belief on the safety of public debts. One direct implication from these result is that the capacity of supplying public debt has the positive impact on its safety.

For supply analysis, Farhi and Maggiori (2017) argue that the safety of public debt served as reserves asset is determined by the stock of debt issuance. In details, under the limited commitment, bonds are safe if their supply is low enough to be on the stable zone but become risky if supply is too high to be on the collapse zone. Indeed, the multiple equilibria relies on the ground that the country who supplies the reserves assets has the monopoly power on issuance of debts. Therefore, it can choose to depreciate its domestic currency to lower the value of debts repaid to foreign investors. Therefore, the paper implies that the supply of public debt could have negative impact on its safety.

Furthermore, we also add other factors on the investigation of public debt safety. On demand side the income per capita can contribute on the establishment of a huge financial market size, since the households use their income to buy financial assets. Moreover, the inflation rate can also have negative impact on the safety of debts since, as documented by Krishnamurthy and Vissing-Jorgensen (2012), in some aspects, US Treasuries can be similar to money on term of liquidity and safety. These two variables jointly contribute on the fundamentals of one economy, which in turn can ensure the public debt safety as supported by He, Krishnamurthy and Milbradt (2017).

On supply side, the trade balance can also affect the public debt safety. Obstfeld and Rogoff (1995) shows that, on one open economy, the current value of debt stock is equal to present value of future trade balances. Therefore, a larger trade surplus can sustain a higher debts issuance, and then, one safer debt. Moreover, the institutional quality such as financial development and political stability can have positive impact on the debt safety, since it underlies the asset's fundamentals. In brief, the theory suggests various factors, on both demand and supply side, which can ensure the public debt safety. 


\subsection{Descriptive Statistics}

The data set is one cross-section sample of about 160 economies. Each variable is the average value over 1980-2013.

The safety of public debts is the sovereign debts ratings, denoted by (asovrate), which is from from World Bank Cross-Country Database of Fiscal Space. The data is constructed by Kose, Kurlat, Ohnsorge and Sugawara (2017) which covers up to 200 countries over period 1960-2016. The debt rating index is ranged from 1 to 21, and a greater index means safer. It illustrates the market perception on a country's ability to roll over debt, or to issue new debt, and on its market cost of borrowing. The index is an annual average of sovereign debt ratings by Moody's, Standard \& Poor's and Fitch Ratings on a daily frequency.

The supply of public debts is measured by the general government gross debt stock per GDP, denoted by $(a g g d y)$. Moreover, we also employ the general government gross debt stock per average tax revenue, denoted by $(a d f g g d)$. Both of these variables are from World Bank Cross-Country Database of Fiscal Space. The former measure of debt rules out the country-size effect by scaling the value of debt by national income, while the latter takes into account the source of financing public debt.

The measurement of debt capacity in reality is one challenging issue. Indeed, since the observed public debts stock can be the equality of demand and supply, it does not reflect the debts capacity of one economy, i.e, the maximum total debts that the country can issue. To overcome this issue, we propose to use the financial market size. Since one economy with huger market size can absorb a greater debt stock, the market size can be proxy for the theoretical debt capacity. In details, the financial market size is measured by the stock market total value traded to Gross Domestic Product (GDP), denoted by (aVal2y). It measures the total value of all traded shares in a stock market exchange. The data is extracted from World Bank Global Financial Development Database.

Other variables are extracted from various sources. In details, the income per capita, denoted by $(a G D P p c)$, is the GDP at constant national 2005 price per population. The financial development level, denoted by (aFinDev), is the domestic credit to private sector per GDP. These two variables are from World Bank Global Financial Development. Moreover, the inflation rate, denoted by $(a c p i)$, is the annual Consumer Price Index (CPI). Together with the trade balance per GDP, denoted by (atb2y), these variables are from World Development Indicators. Finally, the political institutional quality, denoted by (apol), is the political stability and absence of violence index. The data is from the institutional quality dataset constructed by Kunčič (2014).

For instrument variable regression, we employ the average age dependence ratio per 
working-age population, denoted by (aAge) and by the average droughts, floods, extreme temperature per population, denoted by $(a D r o)$. Each variable can raise the public expenditure, which, in turn, can affect the public debts issuance. Moreover, both of them do not affect the market perception on the safety of public debts. Therefore, they can serve as the instrument variables for the public debts.

Table (2.1) illustrates the descriptive statistics for the data sample. The variable starting with $(l n)$ is in $(l o g)$ form. The public debt safety has the mean at (2.39) and standard deviation at (0.41). In comparison with the debt safety, the stock market size has lower mean (1.26) but greater deviation (1.99) while the public debt stock per GDP has much higher mean (3.86) and quite larger deviation (0.69). Other variables also exhibit quite large standard deviations. In short, the data sample offers the rich variation for revealing the determination of public safe assets.

Table 2.1: Descriptive Statistics

\begin{tabular}{lccccc}
\hline \hline Variable & Obs & Mean & Std. Dev. & Min & Max \\
\hline \hline Public Debt Safety (lnasovrate) & 148 & 2.393435 & .416379 & 1.579057 & 3.044523 \\
Stock Market Size (lnaVal2y) & 130 & 1.263306 & 1.997369 & -4.480007 & 5.385939 \\
Public Debt Stock per GDP (lnaggdy) & 186 & 3.862273 & .6976254 & .0863497 & 5.829173 \\
Public Debt Stock per Tax Revenue (lnadfggd) & 182 & 5.73346 & .9408515 & 2.071388 & 9.356496 \\
Income per Capita (lnaGDPpc) & 212 & 8.302932 & 1.474538 & 5.512297 & 11.88601 \\
Inflation Rate (lnacpi) & 178 & 2.335395 & 1.227364 & .140845 & 6.574134 \\
Trade Balance per GDP (atb2y) & 199 & -8.11614 & 17.01324 & -112.2155 & 37.69942 \\
Financial Development Level (lnaFinDev) & 198 & 3.297656 & .7777148 & .9615372 & 5.083573 \\
Political Institutional Quality (apol) & 206 & -.0023531 & .9527779 & -2.709373 & 1.849885 \\
Age Dependence Ratio (aAge) & 194 & 10.15175 & 5.610998 & 2.025247 & 25.28408 \\
Average Droughts per Population (aDro) & 168 & 1.169905 & 1.955153 & 0 & 9.226586 \\
\hline
\end{tabular}

\subsection{Specification And Methodology}

For public debt issued on country $(j)$, its safety determinants are obtained by the following empirical model:

$$
\begin{aligned}
\log \left(\text { asovrate }_{j}\right) & =\alpha+\beta_{1} \log \left(a \operatorname{arl} 2 y_{j}\right)+\beta_{2} \log \left(\operatorname{aggd} y_{j}\right)+\beta_{3} \log \left(\operatorname{aggd}_{j}\right) \log \left(a G D P p c_{j}\right) \\
& +\beta_{4} \log \left(a c p i_{j}\right)+\beta_{5}\left(a t b 2 y_{j}\right)+\beta_{6} \log \left(a \text { FinDev }_{j}\right)+\beta_{7} \log \left(\operatorname{apol}_{j}\right)+\epsilon_{j}
\end{aligned}
$$

The cross-section regression is employed to investigate the determinants of public debt safety. Indeed, by a sample of about 160 economies, the regression can reveal the common pattern of public debt safety across countries. Moreover, since each variable is average value over 1980-2013, the analysis can focus on the long-run determinants of public debt 
safety. In short, the cross-section method is convenient to analyze the public safe assets determination.

We are interested in the role of demand and supply of debt on determining its safety. For the demand analysis, $\left(\beta_{1}\right)$ measures the impact of stock market size on the public debt safety. As implied by He, Krishnamurthy and Milbradt (2016), the expected sign of $\left(\beta_{1}\right)$ should be positive, since a huger market size, one proxy for a higher debt capacity, can raises the investors' perception on the debt's safety.

For the supply analysis, $\left(\beta_{3}\right)$ predicts the impact of debt supply on its safety. The results by Farhi and Maggiori (2017) demonstrates that a more debt issuance can deteriorate the safety. Therefore, $\left(\beta_{3}\right)$ is expected to be negative. For further analysis, we introduce the interaction between the supply of public debt and income per capita, which has the coefficient of $\left(\beta_{3}\right)$. Indeed, the regression can capture the role of income per capita on shaping the dependence pattern of public debt safety on its supply. In short, $\left(\beta_{2}, \beta_{3}\right)$ jointly illustrate the effect of debt supply on the safety.

Finally, we also take into account the role of other variables which are potential to determine the public debt safety. In particular, the demand for debt can be affected by the inflation rate through value of $\left(\beta_{4}\right)$, the trade balance through value of $\left(\beta_{5}\right)$, the financial development level through $\left(\beta_{6}\right)$, and political institution quality through $\left(\beta_{7}\right)$. By detecting the signs of these coefficients, the regression can reveal the roles of various factors on affecting the debt safety, from the source of finance for debt to institutional quality.

\section{Evidences}

\subsection{OLS Estimates}

\subsubsection{Demand Analysis}

Table (3.1) reports the regression results of public debt safety on its determinants. On Column (1), a larger market size improves the safety of public debt. Indeed, $1 \%$ of increase on market size raises the safety index by 1.113. On column (2), the same pattern also hold, by taking into account both income per capita and inflation rate. In particular, the debt safety improves for a higher income per capita, or for a lower inflation rate. On column (3), the institution quality including financial development and political stability exerts the positive impact on the debt safety. Moreover, on controlling for other variables, the impact of stock market size on public debt safety on column (3) is less than on column (1). In brief, the regression establishes that a greater asset demand raises the public debt safety. 
Table 3.1: Cross-Section Regression Results of Public Debt Safety (lnasovrate) on Stock Market Size (lnaVal2y), Income per Capita (lnaGDPpc), Inflation Rate (lnacpi), Financial Development Level (lnaFinDev) and Political Institutional Quality (apol).

\begin{tabular}{|c|c|c|c|}
\hline VARIABLES & $\begin{array}{c}(1) \\
\text { lnasovrate }\end{array}$ & $\begin{array}{c}(2) \\
\text { lnasovrate }\end{array}$ & $\begin{array}{c}(3) \\
\text { lnasovrate }\end{array}$ \\
\hline $\begin{array}{l}\text { Stock Market Size } \\
(\text { lnaVal2y })\end{array}$ & $\begin{array}{c}0.107^{* * *} \\
(0.0146)\end{array}$ & $\begin{array}{c}0.0375^{* * *} \\
(0.0122)\end{array}$ & $\begin{array}{c}0.0342^{* * *} \\
(0.0126)\end{array}$ \\
\hline $\begin{array}{l}\text { Income per Capita } \\
(\text { lnaGDPpc) }\end{array}$ & & $\begin{array}{c}0.184^{* * *} \\
(0.0189)\end{array}$ & $\begin{array}{c}0.111^{* * *} \\
(0.0249)\end{array}$ \\
\hline $\begin{array}{l}\text { Inflation Rate } \\
\text { (lnacpi) }\end{array}$ & & $\begin{array}{c}-0.0630^{* * *} \\
(0.0190)\end{array}$ & $\begin{array}{c}-0.0402^{* *} \\
(0.0185)\end{array}$ \\
\hline $\begin{array}{l}\text { Financial Development Level } \\
\text { (lnaFinDev) }\end{array}$ & & & $\begin{array}{c}0.122^{* * *} \\
(0.0463)\end{array}$ \\
\hline $\begin{array}{l}\text { Political Institutional Quality } \\
\text { (apol) }\end{array}$ & & & $\begin{array}{c}0.0903^{* * *} \\
(0.0315)\end{array}$ \\
\hline Constant & $\begin{array}{l}2.346^{* * *} \\
(0.0364)\end{array}$ & $\begin{array}{c}0.952^{* * *} \\
(0.175)\end{array}$ & $\begin{array}{c}1.096^{* * *} \\
(0.232)\end{array}$ \\
\hline $\begin{array}{l}\text { Observations } \\
\text { R-squared }\end{array}$ & $\begin{array}{c}108 \\
0.335\end{array}$ & $\begin{array}{c}105 \\
0.721\end{array}$ & $\begin{array}{c}105 \\
0.765\end{array}$ \\
\hline $\begin{array}{l}\text { Notes: Standard errors in } \\
\mathrm{p}<0.1 \text {. The regression equatio } \\
\beta_{1} \log (a V a l 2 y)+\epsilon_{j} ; \text { on Column } \\
\beta_{2} \log (a G D P p c)+\beta_{3} \log (a c p i) \\
\alpha+\beta_{1} \log (a V a l 2 y)+\beta_{2} \log (a G \\
\beta_{5} \log (a p o l)+\epsilon_{j} .\end{array}$ & $\begin{array}{l}\text { arentheses. } \\
\text { (2) is: } \log (a s \\
+\epsilon_{j} \text {; on Co } \\
D P p c)+\beta_{3}\end{array}$ & $\begin{array}{l}\text { *** }^{*} \mathrm{p}<0.0 \\
(1) \text { is: } \log ( \\
\text { ovrate })_{j}=\alpha- \\
\text { umn (3) is: } \\
\log (\text { acpi })+\beta\end{array}$ & $\begin{array}{l}* * \quad \mathrm{p}<0.05, * \\
\text { vrate })_{j}=\alpha+ \\
\log (\text { aVal } 2 y)+ \\
(\text { asovrate })_{j}= \\
(\text { (aFinDev })+\end{array}$ \\
\hline
\end{tabular}

Figure 3.1: Stock Market Size and Public Debt Safety

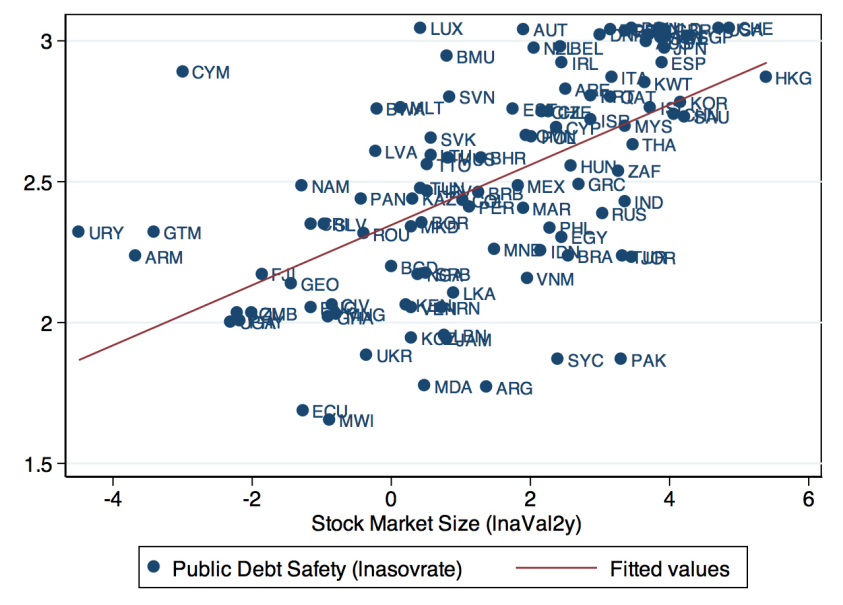


Figure (3.1) illustrates the dependence pattern of public debt safety on the financial market size. One economy with huger market size would have safer public debt. By column (1) on Table (3.1), the slope of fitting curve is exactly equal to 1.113. Let's consider two economies: Mexico with the average market size at $6.17 \%$, and Canada with corresponding value at $40.96 \%$. If the market size of Mexico catches up to the level of Canada, the former's public debt safety could improve by a magnitude of 7.39 , from 12 to 19.39 within the index range from 1 to 21 for debt ratings. In short, the market size plays one important role on ensuring the public debt safety.

\subsubsection{Supply Analysis}

Table 3.2: Cross-Section Regression Results of Public Debt Safety (lnasovrate) on Public Debt Stock per GDP (lnaggdy), Income per Capita (lnaGDPpc), Trade Balance per GDP (atb2y), Financial Development Level (lnaFinDev), Political Institutional Quality (apol).

\begin{tabular}{|c|c|c|c|}
\hline & $(1)$ & $(2)$ & $(3)$ \\
\hline VARIABLES & lnasovrate & lnasovrate & lnasovrate \\
\hline Public Debt Stock per GDP & $-0.120 * *$ & $-0.587 * * *$ & $-0.265^{* * *}$ \\
\hline$(\operatorname{lnaggdy})$ & $(0.0537)$ & $(0.0453)$ & $(0.0636)$ \\
\hline Interaction between (lnaggdy) and (lnaGDPpc) & & $0.0583^{* * *}$ & $0.0257^{* * *}$ \\
\hline$($ inter_GDPpc_ggdy) & & $(0.00383)$ & $(0.00583)$ \\
\hline Trade Balance per GDP & & & $0.00684^{* * *}$ \\
\hline$(a t b 2 y)$ & & & $(0.00191)$ \\
\hline Financial Development Level & & & $0.213^{* * *}$ \\
\hline$(\operatorname{lnaFinDev})$ & & & $(0.0335)$ \\
\hline Political Institutional Quality & & & $0.0649^{* *}$ \\
\hline$($ apol $)$ & & & $(0.0288)$ \\
\hline \multirow[t]{2}{*}{ Constant } & $2.833^{* * *}$ & $2.725^{* * *}$ & $1.841^{* * *}$ \\
\hline & $(0.207)$ & $(0.128)$ & $(0.167)$ \\
\hline Observations & 138 & 137 & 137 \\
\hline R-squared & 0.035 & 0.645 & 0.747 \\
\hline \multicolumn{4}{|c|}{$\begin{array}{l}\text { Notes: Standard errors in parentheses. } * * * \mathrm{p}<0.01, * * \mathrm{p}<0.05, * \mathrm{p}<0.1 \text {. The regres- } \\
\text { sion equation on Column (1) is: } \log (\text { asovrate })_{j}=\alpha+\beta_{1} \log (\text { aggdy })+\epsilon_{j} ; \text { on Column } \\
(2) \text { is: } \log (\text { asovrate })_{j}=\alpha+\beta_{1} \log (\text { aggdy })+\beta_{2} \log (\text { aggdy }) \log (a G D P p c)+\epsilon_{j} \text {; on Column } \\
(3) \text { is: } \log (\text { asovrate })_{j}=\alpha+\beta_{1} \log (\text { aggdy })+\beta_{2} \log (\text { aggdy }) \log (a G D P p c)+\beta_{3} \log (\text { atb } 2 y)+ \\
\beta_{4} \log (\text { aFinDev })+\beta_{5} \log (\text { apol })+\epsilon_{j} \text {. }\end{array}$} \\
\hline
\end{tabular}


Table 3.2 shows the evidences on the supply side of public debt safety determination. On column (1), a higher debt stock reduces the safety of public debt. However, the result on column (2) reveals that the dependence pattern of debt safety on its supply is shaped by income per capita. Indeed, more debt issuance can deteriorate the safety for economies with the income per capita which is less than one threshold of $(\overline{a G D P p c})=23590$ USD at 2005 constant price 1 However, for economies with the income per capita being higher than the threshold, the debt safety accelerates for more debt supply. The same pattern applies on column (3) when the regression controls for other variables. Moreover, the result also reveals that the public debt become safer for the improvement of trade balances and/or of institutional quality. In short, the impact of supply on the debt safety is only positive for economies with high enough income per capita.

Figure 3.2 plots the dependence pattern of public debt safety on its issued stock. On Panel A for full sample, the pattern follows one decreasingly linear fitting curve, with the slope at $(-0.120)$ given by column (1) on Table 3.2 . However, by using the threshold on income per capita $(\overline{a G D P p c}=23590$ USD) to divide the sample into two subsamples, the data uncovers two different patterns. In details, there exists the decreasing one on Panel B with economies of low income per capita and the increasing one on Panel $\mathrm{C}$ with economies of high income per capita. In brief, the dependence pattern of debt safety on the supply is driven by the income per capita.

\subsubsection{Demand and Supply Analysis}

Table (3.3) shows the determination of public debt safety by combination of demand and supply side. On column (1), the impact of supply on the debt safety depends on the income per capita, which is similar to the evidences recorded on Table 3.2 for only supply analysis. And the debt safety is increasing on the stock market size, which is consistent with the results on Table (3.1) for only demand analysis. These patterns also hold by controlling for the inflation rate and trade balance on column (2), and for the financial development and political stability on column (3). In brief, the combination of demand and supply analysis confirms the crucial roles of debt stock and market size on determining the public debt safety.

The threshold on the income per capita tends to increase on controlling for more factors. In details, if the regression takes into account of only debt supply, as on column (2) of Table (3.2), the threshold is at 23590 USD. The addition of stock market size, given on column

\footnotetext{
${ }^{1}$ In details, on column $(2), \log ($ asovrate $)=2.725-0.587 \log ($ aggdy $)+0.0583 \log ($ aggdy $) \log (a G D P p c)$. Therefore, $\frac{\partial \log (\text { asovrate })}{\partial \log (\text { aggdy })}=-0.587+0.0583 \log ($ aGDPpc $) \Rightarrow \frac{\text { dlog(asovrate })}{\partial \log (\text { aggdy })} \geq 0 \Leftrightarrow \log ($ aGDPpc $) \geq$ 10.07. Then, the threshold is obtained as $\overline{a G D P p c}=e^{10.07}=23590$.
} 
Figure 3.2: Public Debt Stock and Public Debt Safety

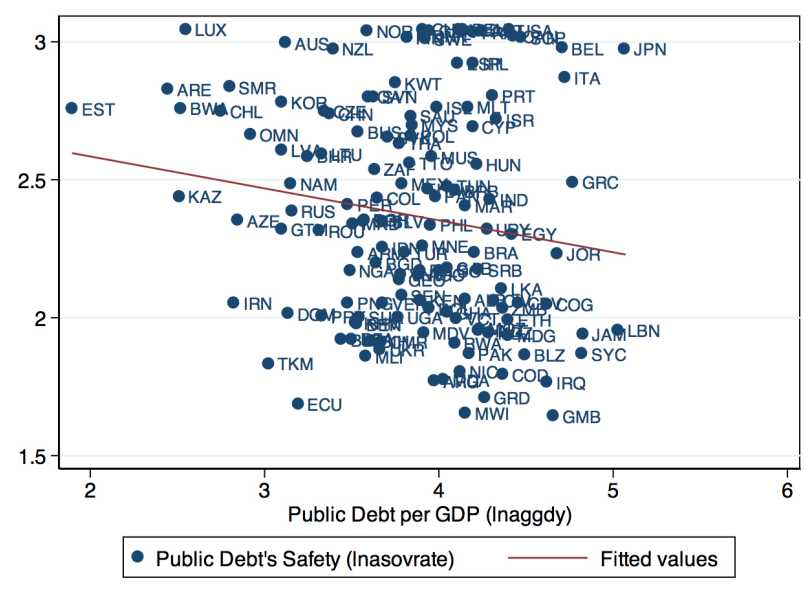

Panel A: Full Sample.

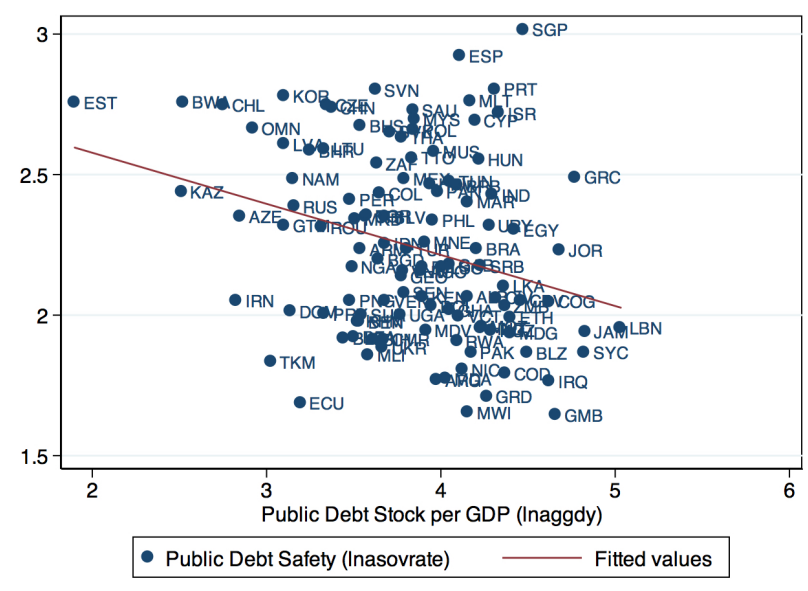

Panel B: Economies with $(a G D P p c<\overline{a G D P p c})$.

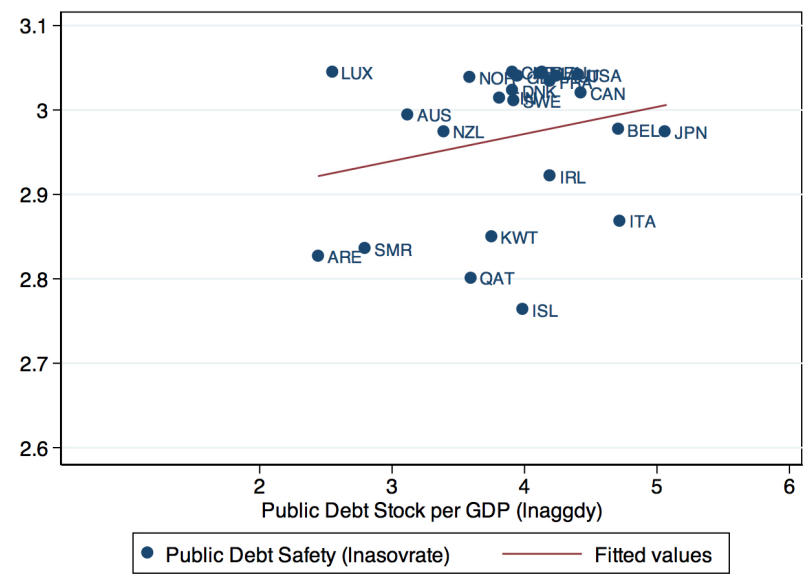

Panel C: Economies with $(a G D P p c \geq \overline{a G D P p c})$ 
(1) of Table (3.3), the threshold raises to 40680 USD. And on controlling for additional factors as on column (3), it even increases to 55599 USD. Therefore, the positive impact of supply on the debt safety can be held only with very high income per capita. The result uncovers that, for one economy, the potential financing source for debt is crucial for the investor perceives the safety of its domestic debt.

Table 3.3: Cross-Section Regression Results of Public Debt Safety (lnasovrate) on Public Debt Stock per GDP (lnaggdy), Stock Market Size (lnaVal2y), Inflation Rate (lnacpi), Income per Capita (lnaGDPpc), Trade Balance per GDP (atb2y), Financial Development Level (lnaFinDev), Political Institutional Quality (apol).

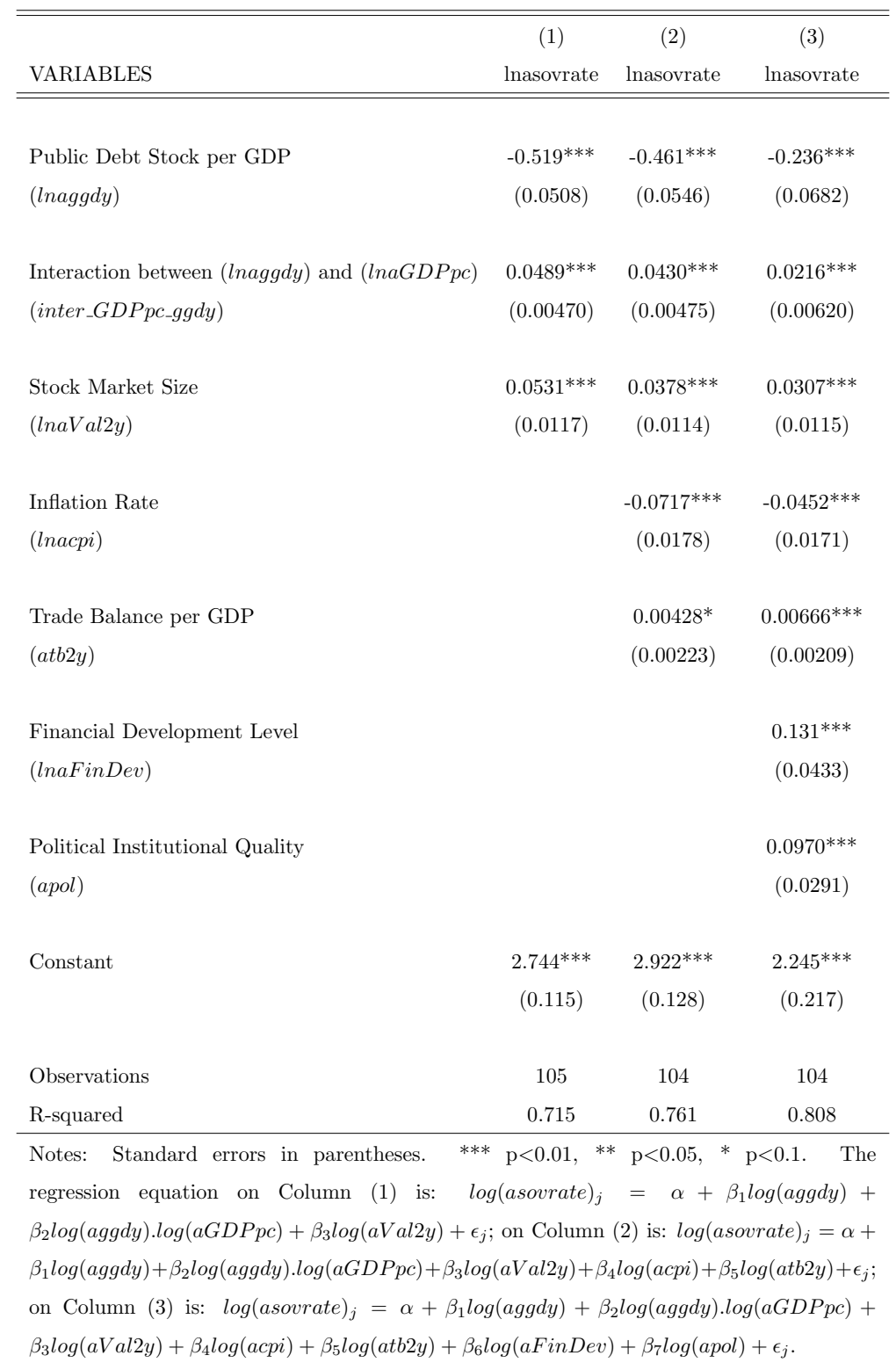


The instrument variable (IV) technique is employed to address the potential endogeneity of the public debt supply on the regression of its safety. On Farhi and Maggiori (2017), the issuance stock affects the debt safety since a too much debt can push the economy into the collapse zone in which the debt becomes risky. However, one economy with safer debt can also have incentive to issue more debt to finance public expenditure. Therefore, the supply of debt may be endogenous on the regression of debt safety.

The debt stock is instrumented by average age dependency ratio per working-age population and by average extreme temperature per population. Firstly, these variables are correlated to the debt stock. Indeed, a higher age dependency ratio expands the pension fund, which in turn can be financed by more public debt. A higher average extreme temperature also unexpectedly raises the public expenditure, which is usually financed by huger debt stock. Secondly, these variables are uncorrelated to the public debt safety. In fact, even on construction of sovereign debt ratings, these variables are not taken into account. In brief, the age dependency ratio and average extreme temperature satisfies the requirement of instrument variables.

Table (3.4) illustrates the IV regression result of public debt safety on its determinants. The instrument variables pass the test of validity. On column (1), the income per capita determines the impact of debt supply on its safety. Indeed, the threshold on income per capita is 27365 USD. The value is close to the value of 23590 USD recorded by column (2) of Table 3.2 and on Figure 3.2 for the cross-section supply analysis. On column (2), the stock market size has positive impact on the public debt safety while the debt supply exerts positive effect on the debt safety only for economies with high income per capita. On column (3), the same patterns applies on controlling for other variables such as the inflation rate, trade balance, financial development and political stability. In brief, the IV regression reveals the similar evidences on the public debt safety determination to the cross-section regressions.

\section{Case Studies: China, Greece and Japan}

Figure (4.1) plots the positions of some economies relative to the threshold on income per capita $(\overline{\operatorname{lnaGDPpc}})=10.07$. Greece and China are on the same group with Republic of Korea on which the public debt safety is decreasing on debt supply. Japan is on group of economies, including United States and Germany, on which the debt safety is increasing on supply. These economies are interesting for more analysis. Greece is at the center of 2009 European debt crisis. And its pattern of public debt safety is crucial for policy dealing with crisis. China, with one huge foreign reserves backed up by high long-run economic 
growth, emerges as one main actor on the global capital market. Japan, which owns one of main world reserve currency (Yen), is facing the increasing debt burden imposed by aging economy and slow economic growth. In brief, each country provides useful case for both economic insights and policy implication.

Figure 4.1: Relative Positions of Some Economies to Threshold on Income per Capita $(\overline{\ln a G D P p c})$. Debt Safety is decreasing on Debt Supply for $(\ln a G D P p c<\overline{\ln a G D P p c})$ and increasing for $(\ln a G D P p c \geq \overline{\ln a G D P p c})$.

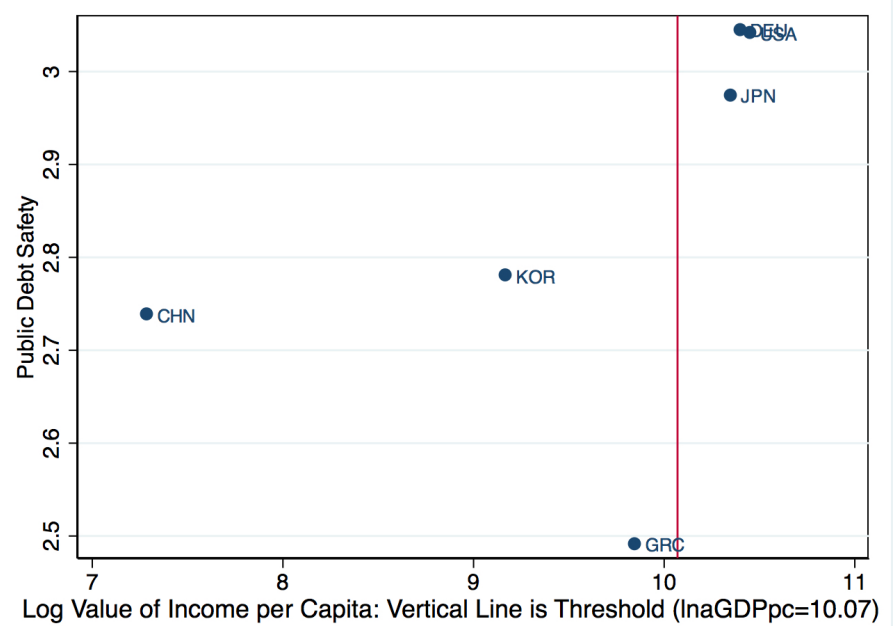

The list of economies includes: China (CHN), Germany (DEU), Greece (GRC), Republic of Korea (KOR), United States (USA) and Japan (JPN).

Table (4.1) reports the predict values and residuals of public debt safety, based on the analysis of both demand and supply on Table 3.3 . Firstly, there exists the difference between predicted value by model and realized one by market for three economies. On case of China, the market perception of public debt safety is more optimistic than the prediction by its economic fundamental. However, on cases of Greece and Japan, the debt safety could be more than the value perceived by investors. Secondly, the prediction by empirical model on column (8) shows that the public debt safety index is higher in Japan than in Greece and China. The difference can be because Japan has greater debt stock, lower inflation rate, more advanced financial development and greater political stability. The similar safety index between China and Greece can illustrate that the advantage of former economy such as less debt stock, huger market size and lower inflation rate compensates for its disadvantage of political institution quality. In brief, in comparison with the prediction based on economic fundamentals, the investors overestimate the debt safety on case of China but underestimate on case of Greece and Japan. 
Table 4.1: Public Debt Safety: Predicted Values and Residuals

\begin{tabular}{|c|c|c|c|c|c|c|c|c|}
\hline Economies & Safety Index & Debt Stock & Market Size & Inflation & Financial Dev. & Political Stab. & Predicted Safety & Residuals \\
\hline (1) & (2) & (3) & (4) & (5) & (6) & (7) & (8) & $(9)=(1)-(8)$ \\
\hline China (CHN) & 15.45703 & 29.10223 & 58.34875 & 5.323359 & 94.25718 & -.4663313 & 13.38383 & 2.073207 \\
\hline Greece (GRC) & 12.07386 & 118.2012 & 14.8625 & 8.512173 & 43.16875 & .254434 & 13.31682 & -1.242968 \\
\hline Japan (JPN) & 19.5733 & 158.7995 & 50.71585 & 3.194004 & 151.0179 & 1.043528 & 20.44216 & -.8688679 \\
\hline
\end{tabular}

The public debt safety on China is analyzed by Panel A on Figure 4.2). Over time, the China debt safety improves along with more debt issuance. The result is inconsistent to the empirical evidences since China is on group of economies for which an increase of debt reduces the debt safety. The potential explanation for the result can rely on the stock market size and income per capita in China. Firstly, on graph B, the acceleration of debt safety is associated with the increase of stock market size over time. The result is just in line with the empirical evidence: greater market size raises the debt capacity, which improves the debt safety. Secondly, the China economy experiences the increase of income per capita over time, which is originated by the high average growth rate over past decades. Therefore, by empirical evidences, higher income per capita can improve the debt safety. In brief, the combination of greater stock market size and higher income per capita can overweight the negative impact of debt stock on public debt safety for the case of China.

The public debt safety determinants for Greece is illustrated by Panel B of Figure 4.2. On demand side (graph B), the changes of debt safety are positively associated with that of stock market size. On supply side (graph A), the pattern of debt safety on its supply changes from the positive correlation over 1990-2008 to negative correlation over 2009-2015. Therefore, the graphs suggest that the occurrence of debt crisis is one key event so that Greece falls on the group of economies for which an increase of debt supply reduces the debt safety. Lane (2012) argues that the Greek crisis relies on the original design of the euro which lacks banking union and other buffer mechanisms. The crisis, on Arghyrou and Tsoukalas (2011), can be driven by the weak macroeconomic fundamentals over 2001-2009, by the shift in market's expectations on the EMU's credible commitment to back up fiscal liabilities. In brief, the case of Greece shows that the crisis can change the dependence pattern of debt safety on its supply. 
Figure 4.2: Public Debt Safety: Supply and Demand

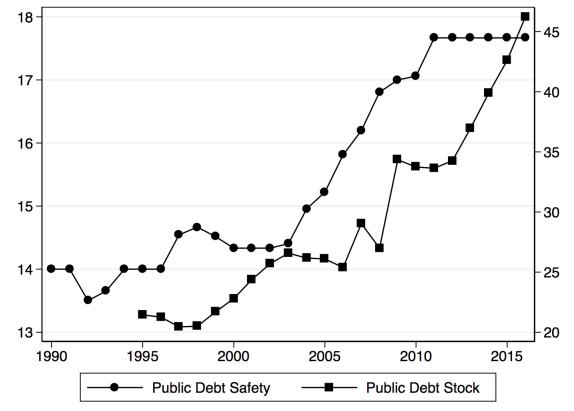

Graph A: Debt Stock

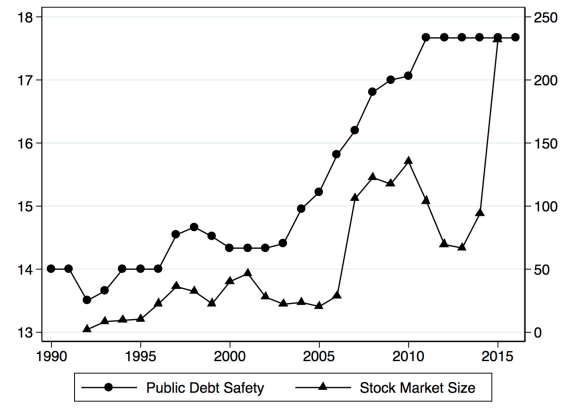

Graph B: Market Size

Panel A: China
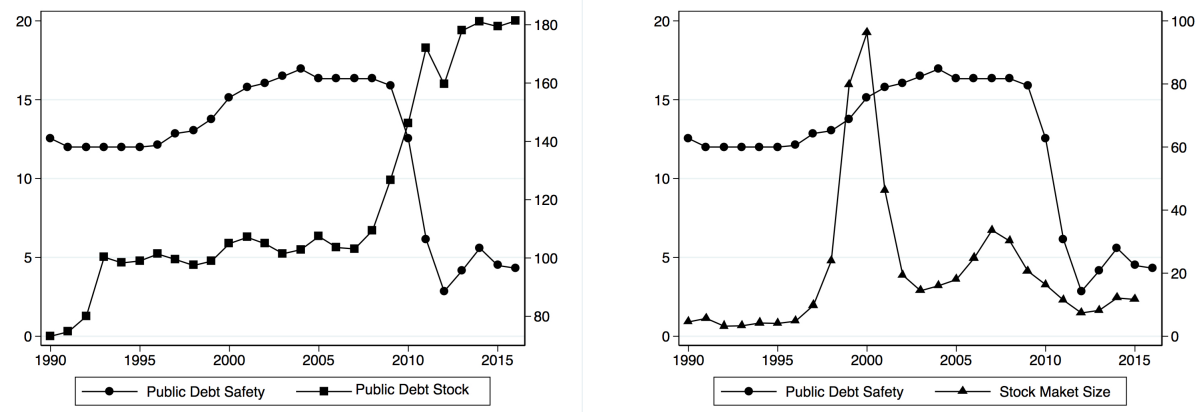

Panel B: Greece

Graph A: Debt Stock

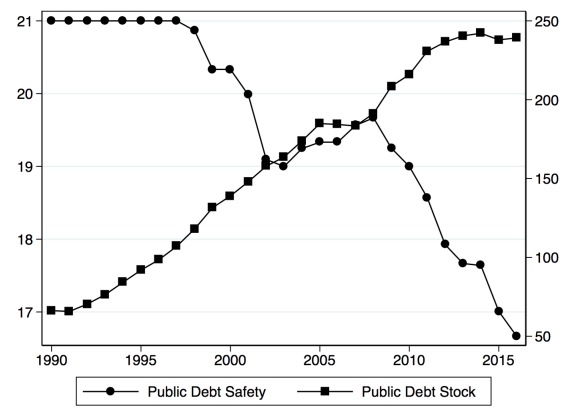

Graph B: Market Size

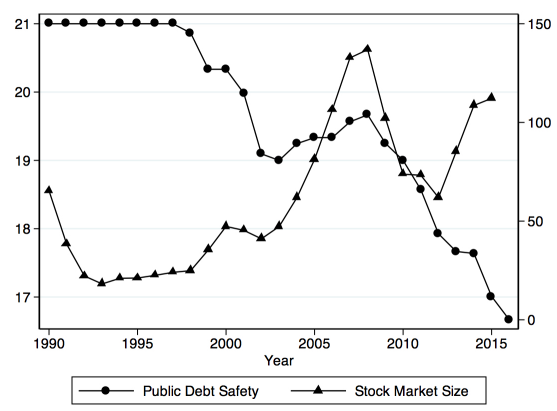

Panel C: Japan

Graph A: Debt Stock

Graph B: Market Size

The case of Japan public debt is plotted by Panel C of Figure (4.2). The data shows that the pattern of Japan debt safety can be inconsistent to the empirical evidences. Indeed, since the economy belongs to group for which the debt safety is increasing on debt supply, the growth of debt issuanece, on graph A, should result on the improvement of debt safety. 
Moreover, the empirical analysis also suggests that the extension of market size, on graph B, can raise the debt safety. However, the safety deteriorates over time in Japan. The deterioration can be attributed to the declining savings induced by aging population, and to the risk appetite attached with financial reform. In details, Tokuoka (2010) shows that the stability of Japan government bonds yields relies on the sizable pool of household savings combined with strong home bias. And on Horioka, Nomoto and Terada-Hagiwara 】 (2014), the robust domestic saving and huge capital inflows have prevented the massive public debt to result on crisis in Japan. These papers suggest that the Japan debt safety can decline if the domestic savings stock dwindles and the households shift their wealth toward riskier assets. Both of two factors reduces the demand for public debt. In brief, for Japan, the decline on debt safety can rely on the demographic changes and risk aversion by households.

\section{Conclusion}

The regressions on one cross-section sample of about 160 economies establish that the public debt safety improves for greater market size, for higher debt stock on the economies with highe enough income per capita. Moreover, the public debt also becomes safer for a lower inflation rate, higher financial development level and better political institution quality.

The result has the implication for public policy on designing the optimal public debt stock for a given safety level. Indeed, one economy with low income per capita should not issue too much debts, since the public debt safety can deteriorate for more debt supply. Moreover, the policies which upgrades the institution quality such as financial system, stabilizes macroeconomic factors such as inflation rate are potential to raise the safety of public debt.

The case studies analyses show that the key determinant of public debt safety can be the income per capita for China, and the demand for debt relied on high household savings for Japan. Moreover, on Greece, the occurrence of debt crisis, grounded by weak fundamentals, has changes the dependence pattern of public debt safety on its supply.

For future research revenue, the analysis can be extended to take into account the role of safe assets determinants on shaping the pattern of public capital flows across countries. Moreover, the investigation of these determinants on the exorbitant privilege gained on safe assets is also one promising future line of research. 


\section{References}

Afonso, Antonio, Pedro Gomes, and Philipp Rother. "Shortand longrun determinants of sovereign debt credit ratings." International Journal of Finance \& Economics 16.1 (2011): 1-15.

Arghyrou, Michael G., and John D. Tsoukalas. "The Greek debt crisis: Likely causes, mechanics and outcomes." The World Economy 34.2 (2011): 173-191.

Bernanke, B. S., Bertaut, C. C., Demarco, L., and Kamin, S. B. (2011). International capital flows and the return to safe assets in the united states, 2003-2007.

Bernanke, Ben S. Causes of the recent financial and economic crisis: testimony before the Financial Crisis Inquiry Commission, September 2, 2010. No. 101. Board of Governors of the Federal Reserve System (US), 2010.

Caballero, Ricardo J., Emmanuel Farhi, and Pierre-Olivier Gourinchas. "Safe asset scarcity and aggregate demand." American Economic Review 106.5 (2016): 513-18.

Caballero, Ricardo J., Emmanuel Farhi. "The safety trap." The Review of Economic Studies 85.1 (2017): 223-274.

Cantor, Richard, and Frank Packer. "Determinants and impact of sovereign credit ratings." (1996).

Dang, T. V., Gorton, G., Holmstrm, B., and Ordonez, G. "Banks as secret keepers". American Economic Review, 107.4 (2017): 1005-29.

Du, Wenxin, Joanne Im, and Jesse Schreger. "The US Treasury Premium." Journal of International Economics (2018).

Farhi, Emmanuel, and Matteo Maggiori. "A Model of the International Monetary System." The Quarterly Journal of Economics 133.1 (2017): 295-355.

Gorton, Gary. "The history and economics of safe assets." Annual Review of Economics 9.1 (2017).

Gorton, Gary B., and Guillermo Ordonez. The supply and demand for safe assets. No. w18732. National Bureau of Economic Research, 2013.

He, Zhiguo, Arvind Krishnamurthy, and Konstantin Milbradt. "A Model of Safe Asset Determination." (2017). 
He, Zhiguo, Arvind Krishnamurthy, and Konstantin Milbradt. "What makes US government bonds safe assets?." American Economic Review 106.5 (2016): 519-23.

Horioka, Charles Yuji, Takaaki Nomoto, and Akiko Terada-Hagiwara. "Why Has Japans Massive Government Debt Not Wreaked Havoc (Yet)?.” The Japanese Political Economy 40.2 (2014): 3-23.

Obstfeld, Maurice, and Kenneth Rogoff. "The intertemporal approach to the current account." Handbook of international economics 3 (1995): 1731-1799.

Kumar, Manmohan S., and Emanuele Baldacci. Fiscal deficits, public debt, and sovereign bond yields. No. 10-184. International Monetary Fund, 2010.

Kose, Ayhan, Sergio Andres Kurlat, Franziska Ohnsorge, and Naotaka Sugawara. "A cross-country database of fiscal space." (2017).

Krishnamurthy, Arvind, and Annette Vissing-Jorgensen. "The aggregate demand for treasury debt." Journal of Political Economy 120.2 (2012): 233-267.

Kunčič, Aljaž. "Institutional quality dataset." Journal of institutional economics 10.1 (2014): 135-161.

Lane, Philip R. "The European sovereign debt crisis." Journal of Economic Perspectives 26.3 (2012): 49-68.

Tokuoka, Kiichi. The outlook for financing Japan's public debt. No. 10-19. International Monetary Fund, 2010.

\section{A Appendix: Robustness Checks}

\section{A.1 Dummy Variable for Advanced Economies}

Table A.1 reports the regression results of public debt safety on its determinants, by two groups of economies. On column (1), the impact of debt stock on its safety differs across advanced and other economies. Indeed, $1 \%$ of increase on debt stock per GDP raises the debt safety index by 1.03 for advanced economies, but reduces the debt safety index by 1.24 for other economies. The reversed signs between two groups are also preserved by addition of stock market size on column (2) and other macroeconomics and institution quality variables on column (3). Moreover, the negative value of coefficient of dummy variable shows that the intercept of linear fitting curve is also different across two groups 
of countries. In brief, the dependence pattern of public debt safety on debt supply differs across advanced and other economies.

Table A.1: Cross-Section Regression Results of Public Debt Safety (lnasovrate) on Public Debt Stock per GDP (lnaggdy), Dummy Variable for Advanced Economies (AdE), Stock Market Size (lnaVal2y), Inflation Rate (lnacpi), Income per Capita (lnaGDPpc), Trade Balance per GDP (atb2y) and Political Institutional Quality (apol).

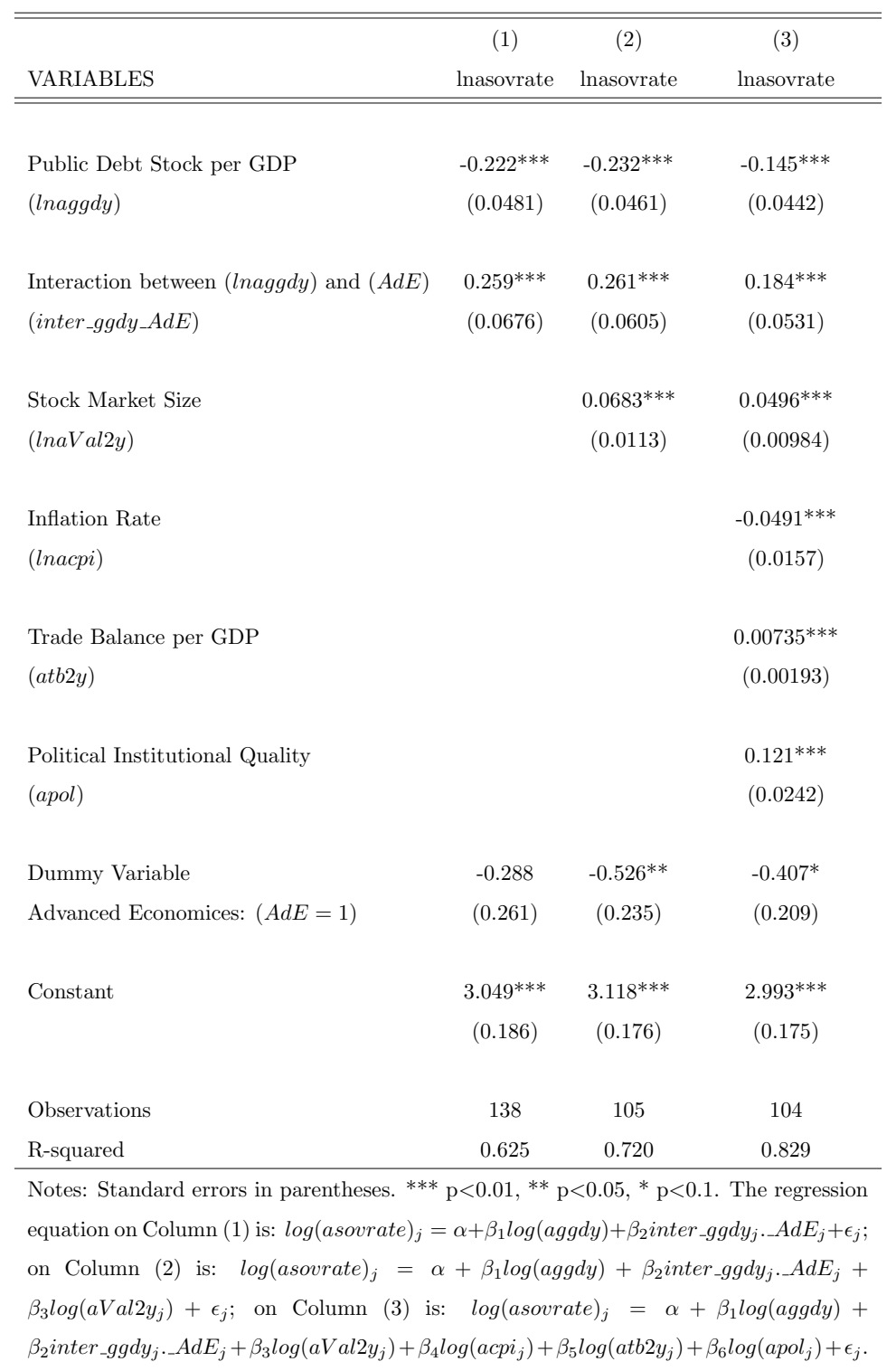

Figure (A.1) illustrates the linear fitting curve for the dependence of public debt safety on its supply. On Panel A for advanced economies, the increasing curve means that an increase of debt supply can raise its safety index. On Panel B for other economies, the decreasing curve confirms that the debt safety deteriorates for more debt issuance. Therefore, the 
separation of countries based on development level provides an alternative evidences on the positive impact of debt supply on its safety on the main text.

Figure A.1: Public Debt Stock and Public Debt Safety

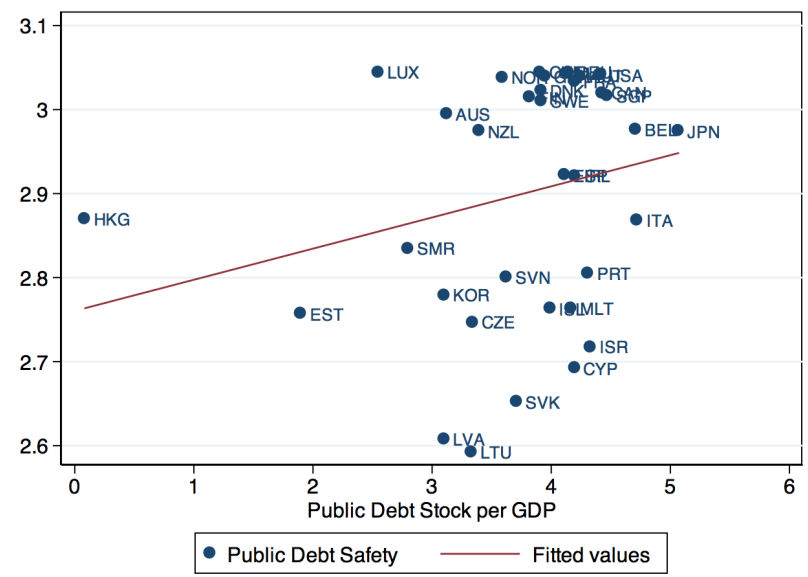

Panel A: Advanced Economies: $(A d E=1)$.

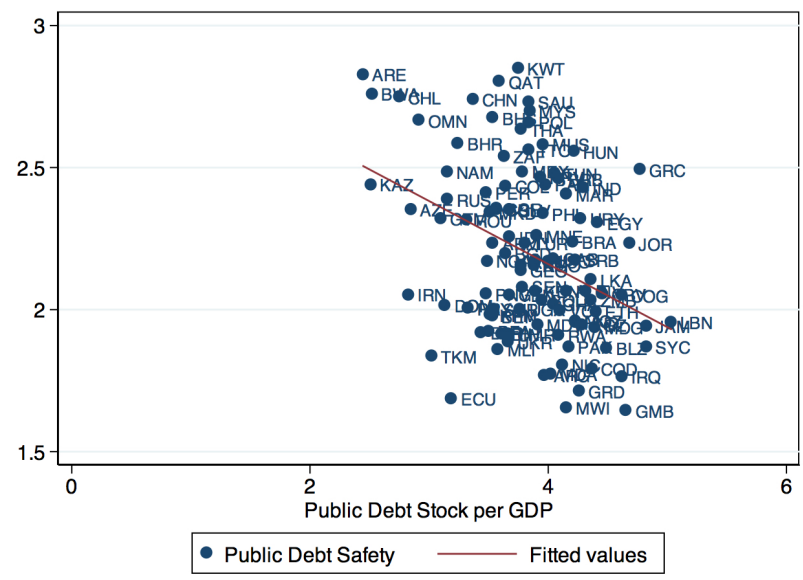

Panel B: Other Economies $(A d E=0)$.

\section{A.2 Alternative Measurement of Public Debt Stock}

The section presents the robustness checks on the evidences on Tables $3.2,3.3,3.4$. In stead of scaling public debt by national income as on main text, we take the ratio of debt stock by the average tax revenues, which is the financing resource for public debt.

The empirical evidences based on the alternative measurement of public debt provide the similar results as on the main text. Table $\mathrm{A} .2$ reports the cross-section regression. On column (1), the public debt safety deteriorates on economies with low income per capita while accelerate on economies with high income per capita. On column (2), the market size 
exerts the positive impact on the debt safety. These patterns also emerge on controlling for other factors on column (3). Furthermore, the IV cross-section regression on Table A.3 shows the same dependence patterns of public debt safety on the debt stock and market size. In short, the results on the main text for the public debt per GDP ratio also applies for the public debt per tax revenues.

Table A.2: Cross-Section Regression Results of Public Debt Safety (lnasovrate) on Public Debt Stock per Tax Revenues (lnadfggd), Stock Market Size (lnaVal2y), Inflation Rate (lnacpi), Income per Capita (lnaGDPpc), Trade Balance per GDP (atb2y), Financial Development Level (lnaFinDev), Political Institutional Quality (apol).

\begin{tabular}{|c|c|c|c|}
\hline VARIABLES & $\begin{array}{c}(1) \\
\text { lnasovrate }\end{array}$ & $\begin{array}{c}(2) \\
\text { lnasovrate }\end{array}$ & $\begin{array}{c}(3) \\
\text { lnasovrate }\end{array}$ \\
\hline $\begin{array}{l}\text { Public Debt Stock per Tax Revenues } \\
\text { (lnadfggd) }\end{array}$ & $\begin{array}{c}-0.403^{* * *} \\
(0.0307)\end{array}$ & $\begin{array}{c}-0.361^{* * *} \\
(0.0361)\end{array}$ & $\begin{array}{c}-0.187^{* * *} \\
(0.0505)\end{array}$ \\
\hline $\begin{array}{l}\text { Interaction between (lnadfggd) and (lnaGDPpc) } \\
(\text { inter_GDPpc_dfggd) }\end{array}$ & $\begin{array}{c}0.0374^{* * *} \\
(0.00263)\end{array}$ & $\begin{array}{c}0.0309^{* * *} \\
(0.00323)\end{array}$ & $\begin{array}{c}0.0135^{* * *} \\
(0.00422)\end{array}$ \\
\hline $\begin{array}{l}\text { Stock Market Size } \\
(\text { lnaVal2y) }\end{array}$ & & $\begin{array}{c}0.0558^{* * *} \\
(0.0119)\end{array}$ & $\begin{array}{c}0.0327^{* * *} \\
(0.0114)\end{array}$ \\
\hline $\begin{array}{l}\text { Inflation Rate } \\
\text { (lnacpi) }\end{array}$ & & & $\begin{array}{c}-0.0598^{* * *} \\
(0.0183)\end{array}$ \\
\hline $\begin{array}{l}\text { Trade Balance per GDP } \\
(a t b 2 y)\end{array}$ & & & $\begin{array}{c}0.00747^{* * *} \\
(0.00201)\end{array}$ \\
\hline $\begin{array}{l}\text { Financial Development Level } \\
\text { (lnaFinDev) }\end{array}$ & & & $\begin{array}{l}0.112^{* *} \\
(0.0450)\end{array}$ \\
\hline $\begin{array}{l}\text { Political Institutional Quality } \\
\text { (apol) }\end{array}$ & & & $\begin{array}{c}0.0863^{* * *} \\
(0.0306)\end{array}$ \\
\hline Constant & $\begin{array}{c}2.862^{* * *} \\
(0.142)\end{array}$ & $\begin{array}{c}2.906^{* * *} \\
(0.139)\end{array}$ & $\begin{array}{c}2.558^{* * *} \\
(0.268)\end{array}$ \\
\hline $\begin{array}{l}\text { Observations } \\
\text { R-squared }\end{array}$ & $\begin{array}{c}136 \\
0.639\end{array}$ & $\begin{array}{c}104 \\
0.708\end{array}$ & $\begin{array}{c}103 \\
0.810\end{array}$ \\
\hline $\begin{array}{l}\text { Notes: Standard errors in parentheses. } \\
\text { regression equation on Column (1) is: } \log \\
\beta_{2} \log (a d f g g d) \cdot \log (a G D P p c)+\epsilon_{j} ; \text { on Column }(2) \mathrm{i} \\
\beta_{2} \log (a d f g g d) \cdot \log (a G D P p c)+\beta_{3} \log (a V a l 2 y)+\epsilon \\
\alpha+\beta_{1} \log (a g g d y)+\beta_{2} \log (a g g d y) \cdot \log (a G D P p c)+\beta_{3} l \\
\beta_{6} \log (a \text { FinDev })+\beta_{7} \log (a p o l)+\epsilon_{j} .\end{array}$ & $\begin{array}{l}\mathrm{p}<0.01, * * \\
\text { asovrate })_{j} \\
; \log (\text { asovra } \\
; \text { on Columr } \\
g(\text { aVal } 2 y)+\end{array}$ & $\begin{array}{l}\mathrm{p}<0.05, * \\
=\alpha+\beta_{1} \\
\text { te })_{j}=\alpha+\beta \\
\text { (3) is: log } \\
\beta_{4} \log (\text { acpi })+\end{array}$ & $\begin{array}{l}<0.1 . \quad \text { The } \\
g(\text { adfggd })+ \\
\text { og }(\text { adf ggd })+ \\
\text { asovrate })_{j}= \\
\log (\text { atb2y })+\end{array}$ \\
\hline
\end{tabular}


